\title{
Compulsory School Is Over and Now? Vocational Experiences of Women with Intellectual Disability
}

\author{
Helga Fasching \\ Department of Education, University of Vienna, Vienna, Austria \\ Email: helga.fasching@univie.ac.at
}

Received 16 April 2014; revised 18 May 2014; accepted 28 May 2014

Copyright (C) 2014 by author and Scientific Research Publishing Inc. This work is licensed under the Creative Commons Attribution International License (CC BY). http://creativecommons.org/licenses/by/4.0/

(c) (i) Open Access

\begin{abstract}
This contribution explores the question of the vocational experiences which women with intellectual disabilities have after leaving school. The main part of the contribution contains an analysis of three interviews with women with intellectual disabilities about their post-school vocational orientation. The research method applied for the analysis was grounded theory. The results show that the three women changed from school directly to a sheltered workshop/occupational therapy or to external vocational preparation measures. They were only able to gain work experience on the regular labour market in the framework of work placement, which led them to express their wish to find employment on the regular labour market. They were successful in their pursuit of vocational participation on the regular labour market. However, they perceive the transition from school to the regular labour market as a cumbersome vocational orientation process.
\end{abstract}

\section{Keywords}

Intellectual Disability, Women, Vocational Orientation/Experience, Work Placement, Vocational Participation

\section{Introduction}

It is the aim of inclusive education to include all children, adolescents and adults equally in inclusive processes of education and training within a framework of life long learning (UN Convention, 2006: Art. 24). This aim suggests that it is relevant to include post-school processes of vocational education and training in research. In this context, it must be analysed which vocational training experiences women and men with intellectual disabilities have after compulsory education. Empirical studies on women and men with intellectual disabilities repea- 
tedly point out the particular experiences of discrimination of this target group, which manifests itself first and foremost in the scarce vocational training and participation and which affects especially women with intellectual disabilities (Lindstrom, Benz, \& Doren, 2004; Baer et al., 2011; Fasching, 2012a, 2013a; Powers et al., 2008; Römisch, 2011; Schildmann, 2010; Umb-Carlsson \& Sonnander, 2006; Winn \& Hay, 2009).

During education and training women with intellectual disabilities already experience manifold barriers in pursuing gainful labour. In most cases they find themselves with a very limited range of possibilities of training, mostly in the form of apprenticeships completing simple tasks in the service sector (Fasching, 2012b; Lindstrom \& Benz, 2002; Umb-Carlsson \& Sonnander, 2006). Even if women with intellectual disabilities are successful in their transition to the labour market, they still end up in the occupational sector which is typically accessed by women with intellectual disabilities (Fasching, 2012b; Powers et al., 2008; Umb-Carlsson \& Sonnander, 2006). As a result of the failure to participate in working life, the target group is often confined to working in their family home, and the life areas of work, self-sufficiency and free time are not clearly separated (Römisch, 2011). As a result, the persons concerned are particularly affected by exclusion from socially relevant activity processes, which is closely related with a lack of possibilities for self-development and self-realisation, as well as with poverty (ILO \& Gaik, 1999).

The two structural categories "sex" and "disability" thus act as indicators of social inequality. Inequality which results from aspects of a person's sex and disability manifests itself particularly in the field of gainful labour, since the valuation and remuneration of the kind of work performed by men and women (in the context of gainful labour) differ depending on the person's sex (Schildmann, 2010): women are discriminated in relation to their reproductive work and/or gainful labour; the same can be observed in connection with disability ("disability" in the sense of reduced productivity in connection with intellectual impairment). This is because all kinds of compensation for reduced productivity received by persons with disabilities "are based on the structures of gainful labour and social security of men and neglect the difficulties faced by women” (Schildmann, 2010: p. 656). This structure affects all areas of society (especially the system of gainful labour and the state, the political community and culture, as well as matrimony and family) and all social conditions (state of citizenship, employment situation, private relationships of the sexes) (Winker \& Degele, 2009: p. 19).

Resulting from the above, in the research field of inclusive education/pedagogics, when considering disability, the aspect of the sex of the person should be taken into account and research must take into consideration the entire life span in order to identify social inequality theoretically as well as in terms of methodology (Schildmann, 2011). It must be the aim of research to systematically explore the effects of social inequalities which are primarily found in the transition period from school to vocational training and employment and which increase the risks of exclusion. The contribution at hand analyses experiences in the life history of women with intellectual impairments (so-called intellectual disability) in their transition period from school to working life. It is particularly this relevant point in life and age, which is when the transition from school to the system of vocational training and employment is made, that is affected by an increase in exclusion mechanisms and/or social inequalities which are, above all, due to the interrelation between the categories of disability and sex.

\section{The Research Project and Initial Results on the Dynamics of Disability and Sex}

An ongoing research project at the Department of Education of the University of Vienna funded by the Austrian Science Fund (FWF) over a period of five years (2008-2013, http://vocational-participation.univie.ac.at/) attempts to gather data on the participation experiences of people with an intellectual impairment diagnosis who are undergoing the transition from school to working life or who are already participating in working life (Biewer, Fasching, \& Koenig, 2009). The aim of the research project is to reconstruct objectively identifiable as well as subjectively experienced participation in the life history of people with intellectual disability undergoing this transition process as well as their participation experiences on the labour market under special consideration of institutional preconditions in Austria. The focus of the research project is on capturing the subjective perspective of the persons concerned by using methods of participative research with intellectually impaired people and by working with reference groups in the process of validating qualitative research data (Koenig, 2012).

For the field of objectively identifiable participation, extensive quantitative as well as various qualitative nation-wide surveys were conducted. The transition process from school to working life in young people with an intellectual disability has already been presented in various publications from the parents' perspective (Fasching, 2012a, 2013a, 2013b; Fasching \& Mursec, 2010), from the teachers' perspective (Fasching, 2012a; Linhart 
2012), and from the perspective of the collaborators of integration measures in the framework of labour market policy (Fasching, 2012b; Fasching \& Koenig, 2010). The results from the analysis of objectively identifiable participation with reference to the structural data show that the transition from school to vocational training and employment is more difficult for women with intellectual disabilities than for men with intellectual disabilities. Young women receive less guidance than young men in vocational orientation processes from their parents and teachers and fewer young women than young men do work placement during school and after leaving school. Furthermore, fewer young women than young men participate in post-school training and qualification measures promoting vocational integration on the regular labour market. Instead, the direct transition from school to a sheltered workshop or occupational therapy is more common in young women than in young men (Fasching, 2013a, 2012b; Fasching \& Mursec, 2010).

Summarising the results of the structural data, it can be concluded that especially during the transition from school to vocational training and employment the interaction between a person's sex and disability develops a special dynamic which is based on the social structure of men's gainful labour and neglects difficulties faced by women (Schildmann, 2010: p. 656).

\section{Case Analysis}

\subsection{Subject of the Analysis and Research Question}

In view of the above, this contribution focuses on the experiences of young women with intellectual disabilities. The interrelation between a person's sex and disability manifests itself not only in structural discrimination but also in regard to representations and identities (Winker \& Degele, 2009).

This contribution looks at the level of identity, i.e. the level of the subjective experience of women with intellectual disabilities. The following question is explored: "What experiences do women with intellectual disabilities have in their transition from school to vocational training and employment?" The empirical data base (biographical interviews) for the contribution at hand is related to the research project and was analysed using the research method of grounded theory (GT). GT is a suitable method for gathering manifold experiences through the subject's narration and for avoiding generalisations. This research approach makes it possible to gain deeper insight into the life histories of young women with intellectual disabilities and gives them a "voice" (Beart, Hardy, \& Buchan, 2004).

Biographical interviews were conducted with a total of 20 young persons with intellectual disabilities in their transition period from school to working life. The young persons with intellectual disabilities were able to give their informed consent for research (meaning, purpose, proceedings and results) (Stalker, 1998). During the interviews, special importance was given to find out what experiences the interviewees considered relevant in their lives and what significance they attributed to these experiences for their lives. For Charmaz (2006: p. 14), it is necessary to immerse oneself in the world of the survey participants; her priority is the gathering of comprehensive data, which are gained through the instrument of "intensive interviewing" and can be seen as the foundation of GT. By asking primarily "How" questions, the interviewees are encouraged to engage in an open narration process. Through their narrations, the interviewees with intellectual disabilities provided the researchers with insight into their life histories. The experiences that they had during their transition from school to vocational training and employment, which is the central topic of the research question, constituted the subject matter of the interviews. Beyond this central topic, other aspects of the narrations included key experiences in the life histories of the interviewees such as experiences of separation during childhood through changing into foster care, divorce of the parents, violence, abuse, moving house and self-supported living, as well as relationships and relationship breakups. The data analysis concentrates on three interviews with women with intellectual disabilities who share the circumstance of having similarly difficult post-school vocational orientation phases while having been successful in their transition to vocational training or employment on the regular labour market.

\subsection{Kathy Charmaz' Constructivist Grounded Theory}

The research process was conducted using Kathy Charmaz' constructivist Grounded Theory Methodology (GTM). Charmaz' guiding methodological principles for the data analysis process are as follows:

“(1) reality is multiple, processual and constructed, but constructed under particular conditions; (2) the research process emerges from interaction; (3) it takes into account the researcher’s positionality, as well as that 
of the research participants; (4) the researcher and researched co-construct the data-the data are a product of the research process, not simply observed objects of it. Researchers are part of the research situation, and their positions, privileges, perspectives and interactions affect it” (Charmaz, 2008: p. 402; Koenig, 2012).

Applying these guiding principles, Charmaz views the interaction between research participants and researchers as a process of co-production and co-construction of data. In addition, in the course of the data collection process the researcher's specific contextual background knowledge of the field of research is to be made transparent.

\subsection{Researcher's Background}

The researcher of this contribution looks back on many years of experience in the field of research into disability as well as practical experience in vocational guidance for persons with intellectual disabilities. Her experiences serve as pre-assumptions or theoretical concepts for the research process. "Theoretical sensitivity" is the ability to identify the relevant data and, by means of theoretical concepts, reflect on the empirical data material (Bryant \& Charmaz, 2007: p. 611). It provides for a sensitive approach to handling data in the analytical process in research into the life histories of persons with intellectual disabilities.

\subsection{Communicative Validation and Reflection}

Communicative validation was performed with the individual research participants. The conceptual framework consisted in the participative research approach applied in the research project, which is implemented primarily by working with a reference group consisting of twelve persons with learning difficulties from various Austrian federal states. For this purpose, reference group meetings were held on a regular basis together with the collaborating researchers in the form of two-day workshops. During these workshops the surveyed life histories of persons with intellectual disabilities were discussed and interpreted with all persons participating in the reference group. Furthermore, meetings were held in which relevant topics - embedded in the life histories of the individual persons - were explored and discussed, and discussions were held on the validation of advanced epistemological processes by using categories (Koenig, 2012; Konzett, 2011). The category system in its "simple language" version was used as a basis for validation. The contents of the discussions were establishment of transparency in the process of epistemological development and adding or changing codes or categories by the participants of the reference groups (Konzett, 2011: p. 82).

\subsection{Analysis: Steps}

The first step in the data analysis consisted in the coding process. With the help of the computer-based software atlas.ti codes can be clearly laid out and interrelated. In Charmaz' constructivist GT the coding process is divided into two phases: the first (initial) phase and a second, focused coding phase. At the beginning a "line-byline coding" of the interview is performed. In the "initial coding" phase the interview material is, so to speak, "split up" in a line-by-line and word-by-word coding process, i.e. it is broken down analytically. The data material is thus no longer a coherent transcript but simply a bunch of disorganised (short and simple) codes. This process helps researchers to move away from the scientific concepts that they are familiar with and to initiate an open process of analysis in order to discover new things in the data.

In the second phase, or focused phase, the data are sorted and synthesized; codes and transcripts are re-read in order to subsequently group the codes into categories. Through the process of constructing codes, first code families (categories) appear, which then are connected to each other. The categories contain the stories and experiences of the three interviewed women. The purpose of the codes in this context is to align the identified categories in such a way that they reproduce a coherent analytic story.

"Theoretical codes are integrative; they lend form to the focused codes you have collected. These codes may help you to tell an analytic story that has coherence. Hence, these codes not only conceptualize how your substantive codes are related, but also move your analytic story in a theoretical direction” (Charmaz, 2006: p. 63).

In a third step the analytic work becomes more theoretical. Theories are created from the codes which are 
again tested against the raw data. Additional data are collected in a controlled way in order to strengthen ambiguous categories or identify new categories. For this purpose "dense" categories are necessary, which are achieved through this third phase in the research process in the form of a theoretical sampling process. The focus of this interview phase is centred on those questions which have arisen due to unclear contents or information still missing for the already existing categories (Charmaz, 2006).

The constructivist GT aims at interpretative theories "and sees both data and analysis as created from shared experiences and relationships with participants" (Charmaz, 2006: p. 130). Constructivists focus on "how" and sometimes "why" research participants construct their specific situation. "A constructivist approach means more than looking at how individuals view their situations. It not only theorizes the interpretative work that research participants do, but also acknowledges that the resulting theory is an interpretation (...). The theory depends on the researcher's view; it does not and cannot stand outside of it” (Charmaz, 2006: p. 130). The theory creation is the result of a construction of codes, categories and sub-categories which are described by means of memos.

\section{Result of the Analysis}

As the possibilities for illustration are restricted in this contribution, only the result of the different steps of the analysis is presented here. The result is thus a first theory creation of the post-school vocational orientation phase in women with intellectual disabilities. In the course of the analysis, the central category of "coming to terms with disability through vocational participation" results from the data analysis of the interviews. This category is first explored in detail in the presentation of the two key categories 1) discrimination at school due to learning difficulties and 2) post-school orientation phase as a process of self-determination) and subsequently presented in a summarised form.

\subsection{Discrimination at School Due to Learning Difficulties (First Key Category)}

The so-called "How" question about the transition from school to working life which was asked at the beginning initially raised the need in the interviewed women to speak about their experiences at school. The three women had negative experiences at school; they carry within them the memories of being excluded at school due to their learning difficulties.

IP1 expresses her primary school experiences as follows: "Because there I had teachers who didn't want anything to do with me at all"1 (IP1). As a consequence of this experience, this pupil had to deal with exam fear. Due to her unsatisfactory performance at school she had to attend a special education centre after primary school; eventually she graduated from secondary school, completing compulsory education. IP2 completed compulsory education in the regular education system. She also said that due to her learning difficulties it was very hard for her to concentrate at school. She noticed that she was discriminated against compared to the other pupils, which she attributes to her learning difficulties. "It was hard for other pupils too, but not as hard as for me, and yet they (teachers) were always nicer to the others than to me (...)." She also had negative experiences with classmates: "We were 22 pupils and they were mucking me about all the time" (IP2). IP3 attended special school; she felt excluded from the regular education system due to her disability. "Because I have a disability, I have Down Syndrome, and so they, I think, they rejected me." She describes school as a negative experience which was "really not nice at all". Friendship experiences at school never lasted long and those friendships were never particularly close.

The young women have lasting and very vivid memories of being discriminated against due to their learning difficulties at school. Statements such as "Others learned faster" or "The others were more accepted", "I wanted to graduate from secondary school but I wasn't allowed to" affect the self-concept of the young women: a lack of self-esteem, a lack of confidence in their own ability to take action, and a lack of career goals were not explicitly mentioned by the women; yet they mark their transition behaviour. Graduating from school for them is merely related to hoping for passive changes. Initially it seems that they did not actively consider vocational training and employment. Ideas about taking on employment simply did not exist for them. The interviewed women initially went from compulsory school to a vocational preparation measure or directly into a sheltered workshop or occupational therapy.

\footnotetext{
${ }^{1}$ The quotations were translated from various German dialects into English. Utteranceslike “ahm” and “mmh” were omitted.
} 


\subsection{The Post-School Orientation Phase as a Process of Self-Determination (Second Key Category)}

IP1 went from vocational preparation into a sheltered workshop; originally she did not want to try out another kind of job: "Well, that would have been a little bit too early after all." (IP1) Her work was entertaining and she got on well with her colleagues, who she also met up with for free time activities. It was only when she started working in a shop, which she enjoyed, that she started to voice her desire to find employment outside the sheltered workshop: "I wanted to work there, but they (the staff in the sheltered workshop) told me that it wasn't a real workplace, because I needn't think that I already have to leave so that I can do something else (...). Yes, I would have liked that. But they told me that at the moment there was no free position because so many people had been there." (IP1) At that moment the career wish of IP1 was to become a shop assistant: "Yes, that would be a great dream." (IP1) By doing work placement, IP1 started to develop ideas about what it could be like to work in a "real job", what it could be like to receive a "real salary". Through further work placements she eventually achieved a definitive full-time position as a clerical assistant. "On the first day, in the first week I thought that I wanted to stay there." (IP1)

IP2 was initially in a vocational preparation measure aiming at finding work. She finally obtained a job helping out in a painting workshop; however, in her surroundings there was no belief that she would be able to manage that job: "First everybody told me that I would never be able to do that, in the painter's shop, and so on and so on. That is way too difficult for you, you will never be able to do that. But then I showed them that I could do it and I was there for a long time." (IP2) After half a year she gave up her job as a painter because she felt abused by her boss. In the meanwhile she is completing a partial qualification apprenticeship as a painter; however, she experiences it as very strenuous. "Well, it's too strenuous for me, so cold in the winter. When you are inside and there is no heating on the site." (IP2) She definitely wants to complete her training as a painter in the partial qualification scheme. Her future perspective is not certain at the moment, which is a burden for her: "Sadness somehow, I don't know, panic maybe, because I will soon be done and I don't know what I want then and I will be unemployed again." (IP2) She definitely wants to find an interesting job.

IP3 went from compulsory school directly to occupational therapy. The job in the occupational therapy became unbearable for her due to the social environment, which she was not comfortable with. It was only at that point that she started thinking about changing jobs, about changing from the sheltered workshop to the regular labour market. She mentioned hoping to work in a company with a pleasant workplace climate and interesting contents. Through work placements she managed to obtain a training position in a partial qualification apprenticeship scheme on the regular labour market, which she completed successfully. This event has a special significance for her: "The only thing that gave me the happiest moment was that I completed the apprenticeship." (IP3)

In their biographies, the interviewees have experiences of repeated rejection in their demands for active codetermination. Ascriptions of disabilities and, related with these, the fact that the persons concerned are not given an opportunity forco- or even self-determination, turn into educational barriers and manifest themselves in the self-concepts of the women. The women must successively work on their demand for normalcy through explicitly expressing "having a real job", "pursuit of an acknowledged training degree". The women start thinking about "a real job" only after they have gained initial work experiences. Gainful labour, the knowledge of such, only emerges when they really engage in it. They learn to differentiate between work in the sheltered workshop and gainful labour with a real salary; they learn to distinguish between interesting work and uninteresting work; they become sensitive towards social processes at the workplace; the make career plans. The women vigorously pursue the goal of changing jobs and obtaining a vocational training degree, connected with the desire for improvement. A burden that they all suffer from is the fear of an uncertain future, a fear of how life might continue after completing training or after changing jobs. For the women, successful vocational participation is related with an interesting occupation in combination with social integration at the workplace. They see as helpful the personal support they receive through guidance which actively assists them in their vocational orientation process, as well as moving out of the parents' house and into self-supported living.

\subsection{Summary of the Main Category: Coming to Terms with Disability through Vocational Participation}

Discrimination at school due to learning difficulties has a negative effect on the self-concept of the persons con- 
cerned and determines their specific transition behaviour. The post-school orientation phase is the result of a slow but continuous self-determination process. This process is marked by an initial phase in which the subjects hope for passive changes; they show a lack of motivation and little initiative in looking for employment. By gaining experiences in the field of employment, this initial phase leads into a phase of reflection on the world of employment and eventually the persons affected embark upon an active process of engaging with this new world. This process of becoming active and the experiences related with it set in motion a process of self-determination in the target group which is pursued with perseverance. The women's demand to take an active part in determining their own life, with the aim of constructing their own subjective identity, manifests itself as a process character, it involves great effort on their behalf. However, the repeated active demands on and defence of their own interests and desires strengthens the self-determination process of the women and can result in a self-determined life. This is another experience that the interviewed women can gain. By having different kinds of positive as well as negative experiences in their transition from school to working life, the women learn to make career-related demands. The desire for a job that suits their interests and for a "real income" develops. As the experience in the field of work grows, so does the urge to act and become involved in decision-taking. This process of getting involved also makes work-related changes possible. Thus we can speak of vocational participation when the transition from school to working life with its manifold challenges has been completed successfully through active engagement and self-determination in pursuit of an interesting job in a socially respected context. Such a transition process can be described as "process of coming to terms with disability".

\subsection{Reflection on the Research Method}

In the analysis example, a main category could be identified which is highly significant professionally as well as politically; along with it, two key categories could be identified. It is worthwhile to explore and reflect on this topic in greater depth. Above all, the reflection in which researchers engage is an important step in realising which of their own concepts and theories they have used in the data collection. This difficulty of engaging in the data collection process with complete objectivity and free from all kinds of premature categorisations concerns especially experienced researchers. Consequently, the codings as created by the researchers cannot be naively viewed as their subjective ones and uncritically involved in the theory creation process. The data collection process in the framework of GT requires a self-critical perspective subject to careful scrutiny, which is best achieved through the exchanges between research participants and researchers. Moreover, exchange took place not only with the researchers involved in the project, but also in small groups in the framework of seminars, working with the research material in terms of content and methodology.

\section{Discussion}

The results of the analysis show that the three women with intellectual disabilities do not have any clear career goals after leaving school. The post-school orientation process was perceived by the women as one of strenuous experiences; nevertheless, they engaged in this process with perseverance. In most cases, when it came to choosing a career in order to be able to organise their life after school in a self-determined way, no support was provided by parents, teachers or professional counsellors. Traditional ideas of parents, teachers and professional counsellors who do not deem necessary the pursuit of some form of vocational training or employment to be able to enjoy an autonomous and self-determined lifestyle seem to persist in spite of the advances in emancipation (Goeke, 2010; Lusk \& Cook, 2009). Traditional ideas start to take hold with the socialisation processes of the women, as in these processes the social services frequently promote dependence and prevent autonomy. The development of self esteem and self assurance is as a general rule barely promoted; however, it is not promoted at all in central areas of life which make possible a lifestyle with true self-determination such as employment and housing. These early biographical experiences of being dependent on others in the contexts of family and school translates into reticence and passivity and manifests itself again very drastically during the transition from school to vocational training and employment when it comes to making their own decisions in an effort to lead a self-determined life (Lindstrom \& Benz, 2002; Lindstrom, Benz, \& Doren, 2004; Umb-Carlsson \& Sonnander, 2006).

\section{Conclusion}

Overall it must be pointed out that there are very few international studies on vocational orientation and qualifi- 
cation of women with intellectual disabilities. This shows that the specific problems of young women with intellectual disabilities concerning vocational orientation and qualification are either not identified or not taken into account. Research on vocational orientation and qualification is therefore absolutely essential in order to achieve successful vocational participation of women with intellectual disabilities.

\section{Acknowledgements}

The author would like to thank the students for the shared time, work and debate in the framework of the analysis of data and the interview partners for the permission to include the results by the author of this article. More information about the research project can be found on the project website:

http://vocational-participation.univie.ac.at/home/

\section{References}

Baer, R. A., Daviso, R., Flexer, R., Mc Mahan Queen, \& Meindl, R. (2011). Students with Intellectual Disabilities: Predictors of Transition Outcomes. Career Development for Exceptional Individuals, 34, 132-141.

Beart, S., Hardy, G., \& Buchan, L. (2004). Changing Selves: A Grounded Theory Account of Belonging to a Self-advocacy Group for People with Intellectual Disabilities. Journal of Applied Research in Intellectual Disabilities, 17, 91-100. http://dx.doi.org/10.1111/j.1360-2322.2004.00186.x

Biewer, G., Fasching, H., \& Koenig, O. (2009). Teilhabe von Menschen mit einer intellektuellen Beeinträchtigung an Bildung, Arbeit und Forschung. SWS-Rundschau, 49, 391-403.

http://www.sws-rundschau.at/archiv/SWS_2009_3_Biewer_Fasching_Koenig.pdf

Bryant, A., \& Charmaz, K. (2007). The SAGE Handbook of Grounded Theory. Los Angeles: Sage.

Charmaz, K. (2006). Constructing Grounded Theory. A Practical Guide through Qualitative Analysis. London: Sage.

Charmaz, K. (2008). Constructionism and the Grounded Theory Method. In J.-A. Holstein, \& J.-F. Gubrium (Eds.), Handbook of Constructionist Research (pp. 397-412). New York: Guilford.

Fasching, H. (2012a). Career Counseling at School for Placement in Sheltered Workshops? British Journal of Learning Disabilities, 42, 52-59.

Fasching, H. (2012b). Partizipation von Frauen und Männern mit intellektueller Beeinträchtigung an arbeitsmarktpolitischen Maßnahmen. Heilpädagogische Forschung, 2, 79-88.

Fasching, H. (2013a). Interaktion von Behinderung und Geschlecht im Übergang von der Schule in Ausbildung und Beschäftigung. Erweiterte Analysen aus einem aktuellen Forschungsprojekt. VHN, 82, 46-59. http://dx.doi.org/10.2378/vhn2014.art04d

Fasching, H. (2013b). The Educational Situation and Transition Process to Work of School Leavers with an Intellectual Disability in Austria. In J. Seifried, \& E. Wuttke (Eds.), Transitions in Vocational Educational Training (pp. 105-122). Opladen: Budrich.

Fasching, H., \& Koenig, O. (2010). Arbeitsmarktpolitische Unterstützungsmaßnahmen in Österreich. Dokumentation der bundesweiten Trägerbefragung arbeitsmarktpolitischer Unterstützungsmaßnahmen. Datenband II der dreibändigen Reihe "Die Übergangs-, Unterstützungs- und Beschäftigungssituation von Menschen mit einer intellektuellen Beeinträchtigung in Österreich”. University of Vienna. http://vocationalparticipation.univie.ac.at/de/publikationen/

Fasching, H., \& Mursec, D. (2010). Schulische Ausgangssituation und Übergang in Ausbildung und Beruf in Österreich. Dokumentation der bundesweiten Befragung der Bezirksschulinspektor/innen und Eltern. Datenband I der der dreibändigen Reihe "Die Übergangs-, Unterstützungs- und Beschäftigungssituation von Menschen mit einer intellektuellen Beeinträchtigung in Österreich”. [Educational Baseline and the Transition to Vocational Training and Employment in Austria. Documentation of the Nationwide Survey of the District Inspector of Schools and Parents. Data Volume I of the Three-Volume Series “The Transition, Support and Employment of People with Intellectual Disabilities in Austria”]. University of Vienna. http://vocational-participation.univie.ac.at/de/publikationen/

Goeke, St. (2010). Frauen stärken sich-Empowermentprozesse von Frauen mit Behinderungserfahrungen. Marburg: Lebenshilfe-Verlag.

ILO, S., \& Gaik, F. (1999). Integrating Women and Girls with Disabilities into Mainstream Vocational Training. A Practical Guide. http://digitalcommons.ilr.cornell.edu/cgi/viewcontent.cgi?article=1169\&context=gladnetcollect

Koenig, O. (2012). Any Added Value? Co-Constructing Life Stories of and with People with Intellectual Disabilities. British Journal of Learning Disabilities, 40, 213-221. http://dx.doi.org/10.1111/j.1468-3156.2011.00695.x

Konzett, M. (2011). Menschen mit Lernschwierigkeiten im Forschungssetting Referenzgruppe. Reflexion über die Bedeutung der Rolle als ForscherIn/ ExpertIn mit Fachwissen im Rahmen der Arbeit in einer Referenzgruppe. Diploma Thesis, Vien- 
na: University of Vienna.

Lindstrom, L., \& Benz, M. (2002). Phases of Career Development: Case Studies of Young Women with Learning Disabilities. Exceptional Children, 69, 67-83.

Lindstrom, L., Benz, M., \& Doren, B. (2004). Expanding Career Options for Young Women with Learning Disabilities. Career Development for Exceptional Individuals, 27, 43-63. http://dx.doi.org/10.1177/088572880402700104

Linhart, J. (2012). Der Einfluss schulischer Berufsorientierung auf den Übergang von der Schule in Ausbildung und Beruf bei jungen Frauen mit intellektueller Beeinträchtigung. Diploma Thesis, Vienna: University of Vienna.

Lusk, S. L., \& Cook, D. (2009). Enhancing Career Exploration, Decision Making and Problem Solving of Adolescent Girls with Disabilities. Journal of Vocational Rehabilitation, 31, 145-153.

Powers, K., Hogansen, J., Geenen, S., Powers, L. E., \& Gil-Kashiwabara, F. (2008). Gender Matters in Transition to Adulthood: A Survey Study of Adolescents with Disabilities and Their Families. Psychology in the Schools, 45, 349-364. http://dx.doi.org/10.1002/pits.20297

Römisch, K. (2011). Entwicklung weiblicher Lebensentwürfe unter Bedingungen geistiger Behinderung. Bad Heilbrunn: Klinkhardt.

Schildmann, U. (2010). Behinderung: Frauenforschung in der Behindertenpädagogik. In R. Becker, \& B. Kortendiek, (Eds.), Handbuch Frauen- und Geschlechterforschung. Theorie, Methoden, Empirie (pp. 654-658). Wiesbaden: Verlag für Sozialwissenschaften.

Schildmann, U. (2011). Verhältnisse zwischen Geschlecht, Behinderung und Alter/Lebensabschnitten als intersektionelle Forschungsperspektive. Journal Netzwerk Frauen- und Geschlechterforschung NRW, 29, 13-15.

Stalker, K. (1998). Some Ethical and Methodological Issues in Research with People with Learning Difficulties. Disability \& Society, 13, 5-19. http://dx.doi.org/10.1080/09687599826885

Umb-Carlsson, O., \& Sonnander, K. (2006). Living Conditions of Adults with Intellectual Disabilities from a Gender Perspective. Journal of Intellectual Disability Research, 50, 326-334. http://dx.doi.org/10.1111/j.1365-2788.2005.00779.x

Winker, G., \& Degele, N. (2009). Intersektionalität: Zur Analyse sozialer Ungleichheiten. Bielefeld: Transcript.

Winn, St., \& Hay, I. (2009). Transition from School for Youths with a Disability: Issues and Challenges. Disability \& Society, 24, 103-115. http://dx.doi.org/10.1080/09687590802535725

UN Convention (2006). Convention on the Rights of Persons with Disabilities. New York: UN Convention. http://www.un.org/disabilities/default.asp?id=259 